\title{
AN ANALYSIS OF VOCABULARY MASTERY OF EIGHTH GRADE STUDENTS AT SMP AMALYATUL HUDA MEDAN
}

\author{
Chris Yovie Sitorus ${ }^{1}$, Mujur Simanjuntak ${ }^{2}$, Sovicana Liontine Sinaga ${ }^{3}$, \\ Natalia Widya Pasca Tarigan 4 \\ Universitas Prima Indonesia \\ ${ }^{1}$ krisyopi27@gmail.com, ${ }^{2}$ mujursimanjuntak20@gmail.com, ${ }^{3}$ liontinsinga@gmail.com, \\ ${ }^{4}$ nataliatarigan@unprimdn.ac.id
}

\begin{abstract}
This study aims an analysis of the student's command of vocabulary. The method used to conduct this study was qualitative design. The data collection for this report, another significant document on the method includes observations, interviews, and testing. The sample used in this paper is 20 students in the eighth grade, one English teacher at SMP SWASTA AMALYATUL HUDA MEDAN. The results showed that the vocabulary of students in Grade 8 was very low, based on an analysis of the data, after the researcher did the study. And the researchers suggest that the English teacher should change the techniques and learning habits to incorporate and expand the vocabulary of students and still make those students feel not bored and difficult, but rather benefit from learning the English language.
\end{abstract}

Keywords: Analysis, Vocabulary Mastery

\section{INTRODUCTION}

A language is a system used to communicate more efficiently to transfer data to others. In culture, this is the one feature of language for expressions to connect well with other people. (Keraf, 2005) offers two understandings of language. The first is the notion of language as a means of communication between members of the public in the form of a sound-symbol created by said human being. Second, Language is a communication system that uses symbols vocal (a speech sound) that are arbitrary. Language is also used as a teaching tool in the learning process. Through the effectiveness of Language, students can improve their abilities, broaden their thinking, and develop their creativity. So, Language is the most important in daily life because people can interact through it with other people around the world, especially in English. English, as a Language in the world, is very important for learning because it can be used to provide or receive information and development education and technology. To prepare English learning for young learners early is very important because their brains and memories are ready and most of them can learn very well. And students must master four English skills to able to communicate effectively. These four skills are Listening, Speaking, Reading, and Writing. At the same time, these four skills also have some aspects one of them is Vocabulary.

Vocabulary is an important thing to know or to learn the English Language. Vocabulary is a language and words used or understood by a person or group of people. And this vocabulary is the basic Language aspect that is mastered before mastering English skills. As stated by (Nathaya, 2013) Vocabulary is one of the important factors in all Language teaching; students must continually learn words as they learn the structure and as they practice sound system "sometimes it's difficult to determine the words that students related to vocabularies such us: meaning, spoken/written forms, collocations, connotations, grammatical behavior, etc. (Linse, 2005) Vocabulary is one of the Languages that should be realized or understood by Language 
learners. To communicate well, vocabulary is a very important role in the teaching and learning process. Teachers and students communicate in the classroom during the learning process to transfer knowledge. Students communicate as they discuss or play to exchange ideas, information, and debate. Through communicate allows someone to share knowledge, information with others and can express themselves. Humans can communicate well if they have sufficient vocabulary. According, (Honby, 1995) Vocabulary is all the words that a person knows or uses and it is all the words in a particular Language. So, we can see that Vocabulary is all the words in a language that is familiar and used by a person to communicate with each other especially in the learning process at school.

Based on observations has been done by researchers in the eighth grade of SMP Swasta Amalyatul Huda Medan, the most difficult language skills are vocabulary. There are some difficulties with vocabulary; First, students have the most difficulty remembering or understanding vocabulary so that students cannot master vocabulary too much. Second, students do not know the type of vocabulary. Students must know the type of vocabulary in English. In this study, the researcher explains the types of vocabulary, namely Nouns, Verbs, Adjectives, and Adverbs. By explaining the types of vocabulary, students find it easier to categorize parts of the vocabulary and they find it easier to master the vocabulary. This research needs to be done because the vocabulary mastery of the eighth grade of SMP Swasta Amalyatul Huda Medan, is still relatively low. Therefore, the researcher analyzes from the results of the interview what causes low vocabulary mastery and the researcher needs to know where the students' difficulties in mastering vocabulary are located.

Based on the background of the study, the problem of study that can be identified are:

1. How is the student's ability to understand the vocabulary of eight grades in junior high school?

2. What are the student's difficulties in the vocabulary of eight grades in junior high school?

Based on the problem of the study, the objective of the study is To find out student's ability to understand the vocabulary of eight grades at junior high school. And to find out the student's difficulties in the vocabulary of eight grades at junior high school.

The researchers focus on an analysis of vocabulary mastery. The researchers made the research subject with a total of 20 eighth grades students of SMP Swasta Amalyatul Huda Medan.

\section{Significance of the Study}

This study will be a benefit:

1. Theoretical benefit

It can be used as academic media for education. And the results of the research paper enrich vocabulary, especially in English teaching.

2. Practical benefit

a. Teacher

The findings of this study can help teachers improve students' vocabulary in the learning process.

b. Student

The finding of this study can improve the quality of vocabulary mastery in the English teaching and learning process for students.

c. Next researcher

The findings of this study hopefully become one expected to be a useful reference for conducted similar research in vocabulary mastery in the teaching and learning process of English. 


\section{METHOD}

The research design used in this study is a Method of Qualitative Research. According to (Saryono, 2010) qualitative research is research that is used to investigate, describe, explain, discover the quality or features of social influences that cannot be explained, measured, or described through a quantitative approach.

In this research, there research approaches used in research design. Descriptive Design is used to help describe the answer with existing questions such as what, who, when, where, and how is related to the research problem. The goal of descriptive research is to describe a phenomenon and it's characteristics. This research is more concerned with what rather than how or why something has happened. Therefore, observation and survey tools are often used to gather data (Gall et al., 2007)The researcher used observed subjects in the environment and analyzed the data in detail which led to the important recommendation. Descriptive Design also often uses observational methods whose results cannot be replicated and serve as instrument measurements and observation.

During a Covid-19 pandemic like this, the researchers is very difficult to find a place to do research, but that does not discourage them, researchers continue to look for schools that remain open, finally, researchers find it is SMP SWASTA AMALYATUL HUDA MEDAN. So researchers can retrieve data in a predetermined way. This study is conducted in December at Smp Swasta Amalyatul Huda Medan, which is located on Jalan Nusa Indah gg Kilang Padi no.44 Pasar 8 Kel. Tj.Mulia Kec.Medan Deli.

This research used the data sources of the student. As sources of data collection, participants in this study were class VIII students at the Amalyatul Huda Junior High Scool in Medan for the $2019 / 2020$ academic year. This learning topic used in this study was to analyze vocabulary skills. The sample used in the study was the eighth grades Junior High School consisting of 20 students.

Research instruments consist of Observation, Test, Interview, and Documentation. The researchers interviews students to analyze a student's vocabulary abilities. With the teaching of vocabulary given to students using the analysis test of student's vocabulary abilities. After teaching the researcher to see the results of the student's vocabulary ability test.

\section{The Technique of Collecting Data}

Research data obtained from qualitative data. Data collection can be done by observing the teaching and learning process between students and teachers in the class, the first is given a test and then interviewed. The purpose of this study will be used as an observation sheet, interview guide and student assessment result in vocabulary skills as a data collection instrument.

The following provides a summary of information on the data collection technique and instrument.

\section{Observation}

Class observation will be carried out to monitor the teaching and learning process in the class. During the observation, the researchers will collect data by observing the class situation. It will be recorded in the form of an observation checklist, field notes, and photographs. The observation checklist will be used to obtain information about the implementation of the planning and the producer of the actions. It will be used to gather data about student's activity during the teaching and learning process. Also, field notes will be used to record facts that cannot be put in the observation forms. The photograph will be used to record facts in a picture. 2. Test 
Researchers gave a test to analyze the student's vocabulary skills. Before administering a test the researcher conducted a test to identify the problem as basic knowledge. Finally, the researcher was about to conduct a test to measure the vocabulary skills of the eighth grades. (Sudjana, 2013) states that: "The test is generally used to assess and measure student learning outcomes, especially cognitive learning outcomes concerning mastery teaching materials following the goals of education and teaching ". Data collection conducted in SMP SWASTA AMALYATUL HUDA which taken data from eight grades. The researcher conducts the tests consist of 20 questions, with the score as follows;

Student's Score $=\frac{\text { Accepted Score }}{\text { Maximal Score }} \times 100$

(Arikunto, 2009)

The criteria of the scores;

\begin{tabular}{ccc}
\hline NO & ITEMS & CRITERIA \\
\hline 1 & $80-100$ & Very Good \\
\hline 2 & $70-79$ & Good \\
\hline 3 & $60-69$ & Enough \\
\hline 4 & $0-59$ & Low \\
\hline
\end{tabular}

\section{Interview}

Interviews were used to analyze students vocabulary skills in this study, researchers will interview students about the complete information regarding the process of learning teaching through data analysis. This data-gathering activity through interviews is used to know student abilities during the interview. The results of the interview are released in the form of a transcript of the interview. The interview instrument is used in qualitative research because it can reveal information across time, which relates to the past, present, and time that will come. And the data generated from the interviews are open, comprehensive, and unlimited, to be able to form complete and deep information reveal qualitative research (Ulfatin, 2014).

4. Documentation

The documentation was taken using a camera as an instrument of this study. Documents in qualitative research are used to complement the interview data and observations that have been made. Documents in qualitative research can be in the form of writings, pictures, or monumental works of the object under study (Suyitno et al., 2014)

\section{The technique of Analyzing Data}

After the researchers collects the data and then the researcher analyzes the data. According to (Sudjana, 2013) "The mean or average is obtained by adding up the scores divided by the number of students" in the simple formula is;

$\mathbf{X}=\frac{\sum \mathbf{X}}{\mathbf{N}}$ 


$$
\begin{aligned}
& \mathbf{X}=\text { the average score } \\
& \sum \mathbf{X}=\text { The Sum of all scores } \\
& \mathbf{N}=\text { number of students }
\end{aligned}
$$

\section{RESULTS AND DISCUSSION}

\begin{tabular}{|c|c|c|}
\hline No & Student's Initial Name & Test \\
\hline 1 & $\mathrm{AF}$ & 40 \\
\hline 2 & ABS & 40 \\
\hline 3 & AR & 50 \\
\hline 4 & $\mathrm{AG}$ & 50 \\
\hline 5 & $\mathrm{BL}$ & 50 \\
\hline 6 & $\mathrm{CK}$ & 80 \\
\hline 7 & DA & 60 \\
\hline 8 & FB & 50 \\
\hline 9 & GCZ & 50 \\
\hline 10 & $\mathrm{HS}$ & 60 \\
\hline 11 & $\mathrm{KE}$ & 65 \\
\hline 12 & MR & 80 \\
\hline 13 & MIP & 40 \\
\hline 14 & NL & 70 \\
\hline 15 & RA & 50 \\
\hline 16 & $\mathrm{RG}$ & 60 \\
\hline 17 & RK & 40 \\
\hline 18 & RT & 75 \\
\hline 19 & SA & 70 \\
\hline 20 & VN & 50 \\
\hline & & $\begin{aligned} \mathbf{X} & =\frac{\mathbf{1 . 1 3 0}}{\mathbf{2 0}} \\
& =56,5\end{aligned}$ \\
\hline
\end{tabular}

\section{Results}

Based on the results of data analysis, the researcher found that the following are;

From the results of the research, there were still many low scores because their level of understanding of vocabulary was still lacking. Therefore, the researchers interviews students and also English teachers about what causes low vocabulary mastery.

\subsection{The results of the interview with a student}




\section{Time and Place of Interview}

Day / Date : Thursday, December 3, 2020

Time $\quad: 09.00-10.00 \mathrm{WIB}$

Place : SMP SWASTA AMALYATUL HUDA MEDAN J1. Nusa Indah Gang KilangPadi No.44 Pasar 8 Kel. Tj.Mulia Kec. Medan Deli.

\begin{tabular}{lll}
\hline No & Questions & Answer \\
\hline 1 & What is your difficulty in understanding vocabulary? & $\begin{array}{l}\text { I think learning vocabulary is } \\
\text { difficult because it is } \\
\text { difficult to interpret, also } \\
\text { difficult to pronounce and } \\
\text { remember. After all, writing } \\
\text { and pronunciation are } \\
\text { different. }\end{array}$ \\
& & \\
& & $\begin{array}{l}\text { So I often watch western } \\
\text { films that have subtitles, and } \\
\text { I record every new } \\
\end{array}$ \\
& What did you do to increase your vocabulary? & into my notes. \\
& & \\
& &
\end{tabular}

\subsection{The result of the interview with a teacher}

\begin{tabular}{|c|c|c|}
\hline NO & Questions & Answer \\
\hline 1 & $\begin{array}{l}\text { How do you respond to } \\
\text { seeing the results of the } \\
\text { eighth-grade vocabulary test? }\end{array}$ & $\begin{array}{l}\text { After seeing the results of this } \\
\text { grade eight vocabulary test, I } \\
\text { saw that there were still many } \\
\text { gaps like their understanding } \\
\text { of the meaning of words. } \\
\text { For low exam scores, I made } \\
\text { a special remedial whose } \\
\text { score was below the KKM. } \\
\text { The remedial is with easier } \\
\text { questions such as mentioning } \\
\text { only some of the vocabulary } \\
\text { in school. } \\
\text { So, after seeing the evaluation } \\
\text { you did here, I had to make a } \\
\text { lot of improvements, } \\
\text { otherwise, I would change the } \\
\text { learning system for the future } \\
\text { so that their comprehension }\end{array}$ \\
\hline
\end{tabular}


of the vocabulary would be even better.

\begin{tabular}{|c|c|c|}
\hline 2 & $\begin{array}{l}\text { What techniques will you do } \\
\text { to change the learning } \\
\text { system? }\end{array}$ & $\begin{array}{l}\text { In the future, to improve the } \\
\text { vocabulary of my students, I } \\
\text { will use game techniques so } \\
\text { that children are more } \\
\text { interested, such as scramble } \\
\text { words or making a note that } \\
\text { at least students know } 20 \\
\text { words in one day. }\end{array}$ \\
\hline 3 & $\begin{array}{l}\text { What are your difficulties in } \\
\text { teaching vocabulary? }\end{array}$ & $\begin{array}{l}\text { There are many problems, the } \\
\text { first is their lack of } \\
\text { comprehension of the } \\
\text { meaning in English, their } \\
\text { vocabulary is still weak. } \\
\text { When they give the topic on } \\
\text { vocabulary, they still do not } \\
\text { understand the meaning of } \\
\text { each word for each word they } \\
\text { want to interpret. or } \\
\text { answering questions on the } \\
\text { meaning or meaning of words } \\
\text { that they do not understand. } \\
\text { This is the most important } \\
\text { thing that has become } \\
\text { difficult for me to teach } \\
\text { vocabulary. } \\
\text { And also I think English is a } \\
\text { different way of writing and } \\
\text { how it is pronounced, my } \\
\text { difficulty is there because } \\
\text { they often make the } \\
\text { pronunciation the same as the } \\
\text { writing. }\end{array}$ \\
\hline
\end{tabular}

Based on the results of the data that the researcher has obtained by conducting tests on students, there are still many students who have a low understanding of vocabulary. From the results of the data obtained by the authors the average value they get is 56.5 in understanding vocabulary. Therefore, seeing the very low results, the English teacher did a new teaching method to improve students' vocabulary understanding, namely by making a game method so that students were more interested and younger in understanding vocabulary.

Five stages were completed (Hatch \& Brown, 1995) to master the vocabulary, namely:

1. Encountering the New Word

2. Getting the Word Form

3. Getting the Word Meaning 
4. Consolidating Word Form and Meaning in Meaning

5. Utilization of the Word.

In the teaching of English, vocabulary plays an important role, such as Wilkins' theory (Thorn Bury 2002:13) which states "without grammar, little can be transmitted; without vocabulary, nothing can be transmitted" and more importantly, Quickly improve your English language proficiency by learning vocabulary. "While linguistic structures are the skeleton of language, vocabulary is the source of vital organs and flesh," said (Harmer, 2007).

Both statements conclude that the importance of vocabulary and communication is higher than grammar. Without knowing grammar, there is little we can express or say. However, without knowing the vocabulary there is absolutely nothing we can express. It will be pointless if the grammatical skills are good, but the mastery of the vocabulary is not sufficient.

\section{CONCLUSION}

Vocabulary is a language and words used or understood by a person or group of people. Students must master four English skills to able to communicate effectively. English, as a Language in the world, is very important for learning because it can be used to provide or receive information. Vocabulary is a language and words used or understood by a person or group of people. This vocabulary is the basic Language aspect that is mastered before mastering English skills. To communicate well, vocabulary is a very important role in the teaching and learning process. Based on the observations has been done by researchers in the eighth grade of SMP Swasta Amalyatul Huda Medan, the most difficult language skills or vocabulary. From the results of the data obtained by the authors the average value they get is 56.5 in understanding vocabulary. Therefore, the English teacher did a new teaching method to improve students' vocabulary understanding, namely by making a game method so that students were more interested and younger in understanding vocabulary.

The researchers suggest that the English teacher should change the techniques and learning patterns to add and improve students' vocabulary and still make those students feel not bored and difficult, but rather benefit from learning the English language.

The techniques suggested by the author to master vocabulary are :

1. Observe and Remember is to test students' ability to observe and remember words.

2. Word Matching is to train the combination of synonyms and antonyms.

3. Blind Fold is to describe vocabulary in the form of a noun.

4. Whisper \& Write (W2) is to practice pronunciation and writing.

5. Simon Says is for memorizing vocabulary in the form of words.

6. Word Wall is sticking large letters in English and their meaning on the classroom wall.

\section{ACKNOWLEDGMENTS}

The authors would like to thank all those on this occasion who have helped me complete this paper. This research is a requirement to complete the English Language and Literature Study Program, Faculty of Teacher Training and Education, Prima Indonesia University. This research is entitled "AN ANALYSIS OF VOCABULARY MASTERY OF EIGHT GRADES STUDENTS AT SMP AMALYATUL HUDA MEDAN". This study will discuss vocabulary mastery. The author gets a lot of help and guidance from various parties. Therefore, the authors would like to thank :

1. Dr. Chrismis Novalinda Ginting, SSiT, M.Kes, As the Rector of the University Prima Indonesia which has provided all the facilities in the process lectures. 
2. Dian Syahfitri, S.S, M.Hum. as Dean of the Faculty of Teacher Training and Science Education, English Language and Satra Study Program, Prima University Indonesia.

3. Natalia Widya Pasca Tarigan, S.Pd., M.Hum. Our supervisor, who is willing to provide motivation and guidance to the author so that research can be finished.

4. Rahmawati, S.Pd., M.Si. Our thesis reviewers, who have been willing to provide motivation and guidance to the author so that this research can be completed.

5. Yenita Br Sembiring, S.S., M.Hum. Head of the English Language and Literature study program who has been willing to provide motivation and guidance to the author so that this research can be completed.

6. Syafrizal. S.E. As Headmaster at SMP SWASTA AMALYATUL HUDA MEDAN.

7. All lecturers and staff of the Language Literature Education Study Program English who has taught and served as well.

8. Especially to our beloved parents and our brothers, sisters, and brothers who are always patient and loyal to give encouragement, motivation, and prayer to us starting from the lecture process and until the assignment this end.

9. Thank you also to our classmates or classmates who have supported us in compiling this research proposal.

10. All parties that we can not mention one by one who has participated as well as assisting in finalizing this proposal, may God Yang The Almighty Bless. Amen.

\section{REFERENCES}

Arikunto, S. (2009). Dasar-dasar Evaluasi Pendidikan. Jakarta: Bumi Aksara, 236.

Gall, M. D., Gall, J. P., Borg, W. R., \& Mendel, P. C. (2007). A guide for preparing a thesis or dissertation proposal in education, for Gall, Gall, and Borg'Educational research: an introduction'and'Applying Educational Research'. Pearson Education.

Harmer, J. (2007). How to teach english. Harlow. Pearson, Longman.

Hatch, E., \& Brown, C. (1995). Vocabulary, semantics, and language education. ERIC.

Honby, A. S. (1995). Oxford advanced learner's dictionary of current English.

Keraf, B. (2005). Learning Second Language. Mataram: NTP Press.

Linse. (2005). Practical Linguis Teaching: young learners. Avenue of American. Journal of English Educational Study, 2.

Nathaya, B. (2013). English vocabulary learning strategies employed by thai tertiary-level students. School of Foreign Languages Institute of Social Technology Suranaree ....

Saryono. (2010). Metode penelitian kualitatif. Bandung:PT.Alfabeta.

Sherman, S. (1996). Telling time: clocks, diaries, and English diurnal form, 1660-1785. University of Chicago Press.

Sudjana, N. (2013). Sudjana, Nana. (2013). Penilaian Proses Hasil Belajar Mengajar. Bandung: Remaja Rosdakarya. Bandung: Remaja Rosdakarya, 109.

Suyitno, S., Sonhadji, A., Arifin, I., \& Ulfatin, N. (2014). Entrepreneurial leadership of vocational schools principals in Indonesia. International Journal of Learning and Development, 4(1), 59-64. 